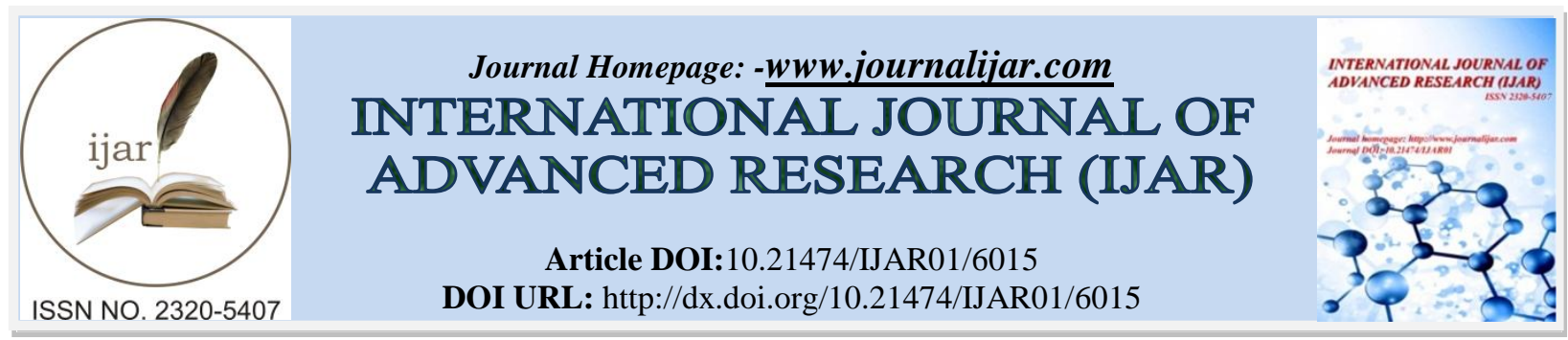

RESEARCH ARTICLE

\title{
EFFECT OF POMEGRANATE (PUNICA GRANATUM) EXTRACT ON NASOPHARYNGEAL CARCINOMA CELL LINES.
}

Nadia Fathy Hassabou, M.D ${ }^{1}$ and Samah M. Kamel, Ph.D ${ }^{2}$.

1. Assistant Lecturer, Oral Pathology Department, Faculty of Dentistry, October 6 University, Egypt.

2. Lecturer, Oral Biology Department, Faculty of Dentistry, Modern Science and Art University, Egypt.

\section{Manuscript Info}

(...........................

Manuscript History

Received: 09 October 2017

Final Accepted: 11 November 2017

Published: December 2017

Key words:-

Punica granatum, antiproliferative, apoptosis and cancer cell lines.

\begin{abstract}
Background and Aim: Head and neck cancer is common in several regions in the world. Nowadays, natural compounds are important resources of many anticancer drugs. Punica granatum has been demonstrated to possess anticancer effects on various types of cancer cells. It is a kind of antioxidant rich fruit, as its peels and seeds have potential anticancer activities. In this study, we aimed to investigate the antiproliferative and apoptotic effects of punica granatum extract on nasopharyngeal carcinoma cell lines.

Material and Methods: A pure extracts from seeds and peels of punica granatum were added to nasopharyngeal carcinoma cell line and to normal cell line as a control group. Expression of Bax, Bcl-2 and p53 genes was evaluated.

Results: Anti-proliferative effects of punica granatum demonstrated the highest cytotoxic effect against nasopharyngeal carcinoma cell line after $24 \mathrm{hrs}$ which increased by increasing the time of influence. We observed no anti-proliferative effects on the healthy cell line. Expression of Bax and p53 genes revealed a highly significant increase in cancer cell lines $(\mathrm{p}=0.00001)$ compared to normal cell line. In addition to highly significant decrease $(\mathrm{p}=0.0006)$ in $\mathrm{Bcl}-2$ of cancer cells in comparison to normal cells.

Conclusions: Punica granatum exert potent cytotoxic and antiproliferative effects on nasopharyngeal carcinoma cell line.
\end{abstract}

Copy Right, IJAR, 2017,. All rights reserved.

\section{Introduction:-}

Head and neck cancer is considered one of the commonest cancers in the worldwide which has an increased rate of mortality that accounts for more than 550,000 cases and 380,000 deaths annually (Global Burden of Disease Cancer Collaboration, 2017). Conventional treatment modalities for most head and neck cancers usually consist of surgery, chemotherapy and radiotherapy. Although, these modalities are toxic to cancer cells, they show several side effects on the normal cells due to targeting some healthy active cells leading to their damage (Saini et al., 2012).

Researchers have attempted to discover therapeutic agents that attain their cytotoxic effects by provoking apoptosis in cancer cells with minimum or no side effects on normal cells (Felipe et al., 2014; Shojaee et al., 2014 and Ahmadi 
et al., 2015). Nowadays, decreased toxicity, increased effectiveness and low cost of the herbal medicine offer better modalities for prevention and treatment of cancer (Kuppusamy et al., 2013).

Pomegranate (Punica granatum) is obtained from long-living tree cultivated throughout the Mediterranean region and Northern India (Jurenka, 2008). Pomegranate fruit is a rich source of many phenolic compounds including anthocyanins, ellagitannins and ellagic acid esters of glucose (Shirode et al., 2014).

Pomegranate seeds have potent anti-inflammatory and antioxidant properties due to their higher concentration of polyphenols than other recognized fruits, red wine and green tea. Pomegranate antioxidant effect appears unique as compared to the antioxidant activity of ascorbic acid, vitamin $\mathrm{E}$ and carotene due to combinations of a broader array of polyphenols, having a wide range of action against several types of free radicals (Sharma et al., 2017).

Studies have shown that pomegranate and its constituents can efficiently affect numerous signaling pathways involved in inflammation, cellular proliferation, transformation, angiogenesis, initiation or suppression of tumorigenesis and metastasis (Faria and Calhau, 2011). Naturally occurring substances of pomegranate are shown to modulate pro-apoptotic and anti-apoptotic proteins which play an important role in the eradication of cancer cells (Portt et al., 2011 and Kuppusamy et al., 2013). The programmed cell death is applied through a pathway of selfdestruction and marked by biochemical and morphological indicators as reducing of cell volume and DNA fragmentation (Thangam, 2014).

Since previous studies have demonstrated the anticarcinogenic activity of pomegranate extracts in a series of human cancer cells with the main focus of researches has been on prostate and breast cancer (Dai et al., 2010; Deng et al., 2017; Seidi et al., 2016 and Shirode et al., 2014), this study was aimed to examine the antiproliferative and apoptotic effect of punica granatum extract on nasopharyngeal carcinoma cell lines.

\section{Material and Methods:-}

Plant materials and Preparation of Extract:-

According to the method previously described by (Baeshen et al., 2012) the seed parts and peels were separated, dried and grounded into fine powder using a blender. The extract was concentrated by rotary evaporator and stored at $-20^{\circ} \mathrm{C}$ at the National Research Institute, Egypt. To prepare the aqueous and ethanolic extract the ground herb was soaked in water (aqueous extract) or $70 \%$ ethanol (ethanol extract) for $24 \mathrm{hrs}$, then, the mixtures were filtered and passed sequentially through a $0.22 \mu \mathrm{m}$ filter sterilization and kept in aliquots at $4^{\circ} \mathrm{C}$. Briefly, the concentrated plant extracts were dissolved in dimethylsulphoxide (DMSO) (SIGMA, USA) to get a stock solution of $10 \mathrm{mg} / \mathrm{mL}$.

\section{Cell Culture:-}

Cell lines (C666-1) were obtained from undifferentiated nasopharyngeal carcinoma and were provided by the Holding Company for Biological Products \& Vaccines, Egypt (VACSERA). Cells were cultured in RPMI 1640 medium (Gibico, USA) supplemented with 10\% fetal bovine serum (Sijixin Inc., China) and 1\% penicillinstreptomycin (Invitrogen, USA) at $37^{\circ} \mathrm{C}$ in a $100 \%$ humidified atmosphere containing $5 \% \mathrm{CO} 2$.

Punica granagtum extract was added to nasopharyngeal carcinoma cell lines and to a healthy cell lines that have been used as a control. PCR was done after incubation for 24 and $48 \mathrm{hrs}$ at $37^{\circ} \mathrm{C}$.

\section{PCR Methodology:-}

DNA and RNA were extracted from cells using quantitative real- time PCR.

\section{Quantitative real- time PCR:- RNA extraction:-}

According to instructions of manufacture total RNA was isolated using Qiagen extraction kit (Qiagen, USA). RNA isolation was performed on in-vitro cells. Nasopharyngeal carcinoma cells were centrifuged for $3 \mathrm{~min}$. at full speed. The supernatant was removed and transferred to a new microcentrifuge tube. One volume ( $350 \mu \mathrm{l})$ of $70 \%$ ethanol was added to the cleared lysate.

About $700 \mu$ of the sample was transferred to an RNeasy spin column that was placed in a $2 \mathrm{ml}$ collection tube and centrifuged for $15 \mathrm{sec}$. at $\geq 8000 \mathrm{rpm}$. $700 \mu \mathrm{l}$ Buffer RW1 was transferred to the RNeasy spin column and

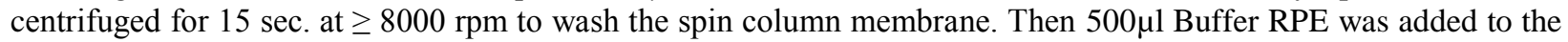

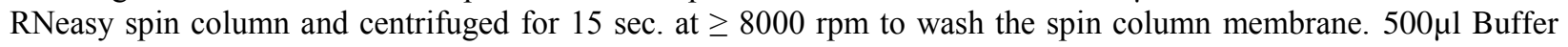


RPE was added to the RNeasy spin column and centrifuged for 2 min at $\geq 8000 \mathrm{rpm}$ to wash the spin column membrane again.

RNeasy spin column was placed in a new $1.5 \mathrm{ml}$ collection tube. 30-50 $\mu 1$ RNase-free water was added directly to the spin column membrane and centrifuged for $1 \mathrm{~min}$ at $\geq 8000 \mathrm{rpm}$ to elute the RNA.

The eluted RNA was transferred to a new Eppendorf tube and stored at $-80{ }^{\circ} \mathrm{C}$ for further use. The purity (A260/A280 ratio) and the concentration of RNA were obtained using spectrophotometry (dual wave- length Beckman, Spectrophotometer, USA).

\section{Sequence of primers:-}

\section{Real-Time PCR primers:-}

Primers sequence (5' to 3 ') for all studied genes are demonstrated (table 1).

Table 1:-Primers sequence for all studied genes:

\begin{tabular}{|l|l|l|l|}
\hline \multicolumn{1}{|c|}{ Gene } & \multicolumn{2}{|c|}{$\begin{array}{c}\text { Primer } \\
\text { type }\end{array}$} & $\begin{array}{l}\text { Primer sequences (5' to 3') } \\
\text { CTACTAAGGTCGTGAGACGCTGCC } \\
\text { TCAGCATACAGGTTTCCTTCCACC } \\
106\end{array}$ \\
\hline P53 & RT-PCR & $\begin{array}{l}\text { Forward } \\
\text { Reverse }\end{array}$ & $\begin{array}{l}\text { CCAGGACGCATCCACCAAGAAGC } \\
\text { TGCCACACGGAAGAAGACCTCTCG } \\
136\end{array}$ \\
\hline BCL-2 & RT-PCR & Forward & $\begin{array}{l}\text { GGATGACTTCTCTCGTCGCTACCGT } \\
\text { ATCCCTGAAGAGTTCCTCCACCAC } \\
118\end{array}$ \\
& RT-PCR & Forward & Reverse \\
\hline GAPDH & RT-PCR & Forward & $\begin{array}{l}\text { ATGGAGAAGGCTGGGGCTCACCT } \\
\text { AGCCTTCCACGATGCCAAAGTTGT } \\
209\end{array}$ \\
\hline
\end{tabular}

\section{cDNA Synthesis:-}

The total RNA $(0.5-2 \mu \mathrm{g})$ was used for cDNA conversion using high capacity cDNA reverse transcription kit Fermentas, USA).

\section{Reagents and Equipment:-}

Moloney murine leukemia virus (MMLV) reverse transcriptase was used for the synthesis of cDNA from RNA. It is an RNA- dependent DNA polymerase that uses single- stranded RNA as a template in the presence of a primer to synthesize a complementary DNA strand.

Human Placental Ribonuclease Inhibitor (HPRI) was used for inhibition of RNase activity. First strand buffer: Provides preferred $\mathrm{pH}$ and ionic strength for reverse transcription. Deoxynucleotide triphosphate (dNTPs) dATP, dTTP, dGTP, dCTP were used for extension of primers.

Random hexamers: primers for reverse transcription of RNA (Stratagene), DEPC- treated water and thermal cycler (Biometra, USA) were used.

\section{Procedure:-}

Three $\mu \mathrm{l}$ of random primers were added to the $10 \mu \mathrm{l}$ of RNA which was denatured for 5 minutes at $65^{\circ} \mathrm{C}$ in the thermal cycler. The RNA primer mixture was cooled to $4^{\circ} \mathrm{C}$. The cDNA master mix was prepared according to the kit instructions and was added for each sample. 
The total volume of the master mix was $19 \mu$ f for all samples. This volume was added to the $31 \mu \mathrm{l}$ RA-primer mixture resulting in $50 \mu \mathrm{l}$ of cDNA. The last mixture was incubated in the programmed thermal cycler for one hour at $37^{\circ} \mathrm{C}$ followed by inactivation of enzymes at $95^{\circ} \mathrm{C}$ for 10 minutes and finally cooled at $4{ }^{\circ} \mathrm{C}$. Then RNA was changed into cDNA. The converted cDNA was stored at $-20{ }^{\circ} \mathrm{C}$.

\section{Real-time qPCR using SYBR Green I:-}

Real-time qPCR amplification and analysis were performed using an Applied Biosystem with software version 3.1 (StepOne ${ }^{\mathrm{TM}}$, USA). The qPCR assay with the primer sets were optimized at the annealing temperature. All cDNA were duplicated and including previously prepared samples.

\section{Preparation of the reaction master mix for Q-PCR:-}

For each sample the following reagents and volumes were added: $1 \mu \mathrm{l}$ of each (forward primer and reverse primer), $5 \mu \mathrm{l}$ of each (cDNA template and RNAse free water) and $12.5 \mu \mathrm{l}$ of Syber green mix.

Running condition for RT-PCR:-

Table 2:-Systems and thermal cycling conditions for RT-PCR

\begin{tabular}{|l|c|c|c|}
\hline \multirow{2}{*}{ System } & \multicolumn{3}{|c|}{ Thermal cycling condition } \\
\cline { 2 - 4 } & Stage & Temp. & Time \\
\hline \multirow{3}{*}{$\begin{array}{l}\text { Applied Biosystems } \\
\text { RepOne }\end{array}$} & Hold & $50^{\circ} \mathrm{C}$ & $2: 00$ \\
\cline { 2 - 4 } & & One cycle & $0: 15$ \\
\cline { 2 - 4 } & Denaturation & $95^{\circ} \mathrm{C}$ & $1: 00$ \\
\cline { 2 - 4 } & Annealing & $60^{\circ} \mathrm{C}$ & $1: 00$ \\
\cline { 2 - 4 } & Extension & $72^{\circ} \mathrm{C}$ & \\
\cline { 2 - 4 } & \multicolumn{3}{|c|}{40 cycles } \\
\hline
\end{tabular}

Calculation of Relative Quantification (RQ) (Relative Expression):-

$C t=P C R$ cycle

A typical qPCR run has around 40 cycles. The $\mathrm{Ct}$ is the value where the PCR curve crosses the threshold in the linear part of the curve. It's the value that will be used for the analysis.

\section{Endogenous Controls:-}

It is the gene that does not vary between all of the samples tested. Typically have a smaller $\mathrm{Ct}$ then regular genes.

\section{Calibrator:-}

The calibrator is the sample that all others are compared to. It's the "untreated" or "time zero". The RQ of the calibrator is 1 because it does not vary compared to itself.

$\Delta \mathrm{Ct}=\mathrm{Ct}$ gene test $-\mathrm{Ct}$ endogenous control

$\Delta \Delta \mathrm{Ct}=\Delta \mathrm{Ct}$ sample $1-\Delta \mathrm{Ct}$ calibrator

$\mathrm{RQ}=$ Relative quantification $=2^{-\Delta \Delta \mathrm{Ct}}$

The RQ is a technique used to analyze the fold changes in gene expression in a given sample compared to a calibrator; a reference sample (such as an untreated control sample, time zero, etc.).

\section{Statistical Analysis:-}

Scores of overall genes expression were represented as mean values and standard deviation using SPSS (Statistical Package for Social Sciences) 10.3 software. Student's t-test was used to compare the mean values between the studied groups. P-value was considered highly significant when $\leq 0.01$ and significant when $\leq 0.05$. Pearson correlation test was also used. $\mathrm{R}$ value was considered weak relation when the value is near to zero

\section{Results:-}

The current results showed antiproliferative and cytotoxic effects of punica granatum extract against malignant cells of nasopharyngeal carcinoma cell lines after 24 hours which is time - dependant that was increased after 48 hours of influence.

We observed no antiproliferative effects of the punica granatum extract on the healthy cell lines that have been used as a control group. 
Antiproliferative and cytotoxic effects of punica granatum are represented as mean values of gene expression (table 3). Highly significant increase in the expression of BAX and p53 ( $\mathrm{p}=0.00001$ for both) was observed in cancer cell lines compared to normal cell lines. While $\mathrm{Bcl}-2$ gene expression revealed a highly significant decrease $(\mathrm{p}=0.0006)$, (graph 1).

Weak positive correlation has been demonstrated between the normal cell lines in relation to time of influence $(\mathrm{R}=$ 0.4407 , graph 2) while weak negative correlation has been revealed in cancer cell lines $(\mathrm{R}=-0.155$, graph 3$)$.

Table 3:-Mean values of studied genes expression in control and cancer cell lines (Time - dependant):

\begin{tabular}{|c|c|c|c|c|c|c|}
\hline & \multicolumn{2}{|c|}{ BAX } & \multicolumn{2}{c|}{ BCL-2 } & \multicolumn{2}{c|}{ P53 } \\
\hline Time /hrs & 24 & 48 & 24 & 48 & 24 & 48 \\
\hline Control cell lines & 1.02 & 1.09 & 1.01 & 0.09 & 1.04 & 1 \\
\hline $\begin{array}{c}\text { Cancer cell lines } \\
\text { with added extract }\end{array}$ & 4.2 & 5.7 & 0.43 & 0.26 & 5.9 & 6.7 \\
\hline
\end{tabular}

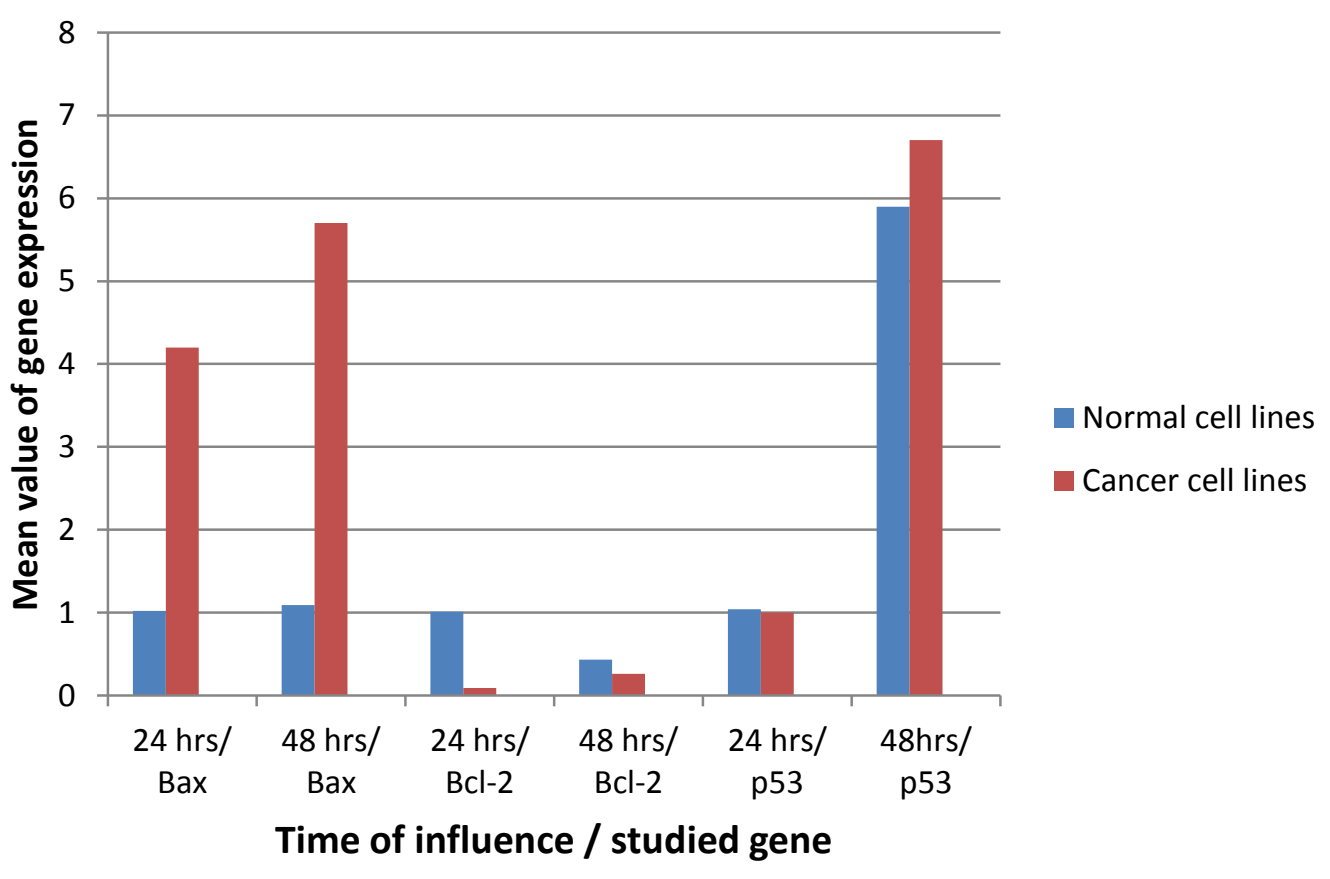

Graph1:-Mean values of gene expression in normal and nasopharyngeal carcinoma cell lines. 


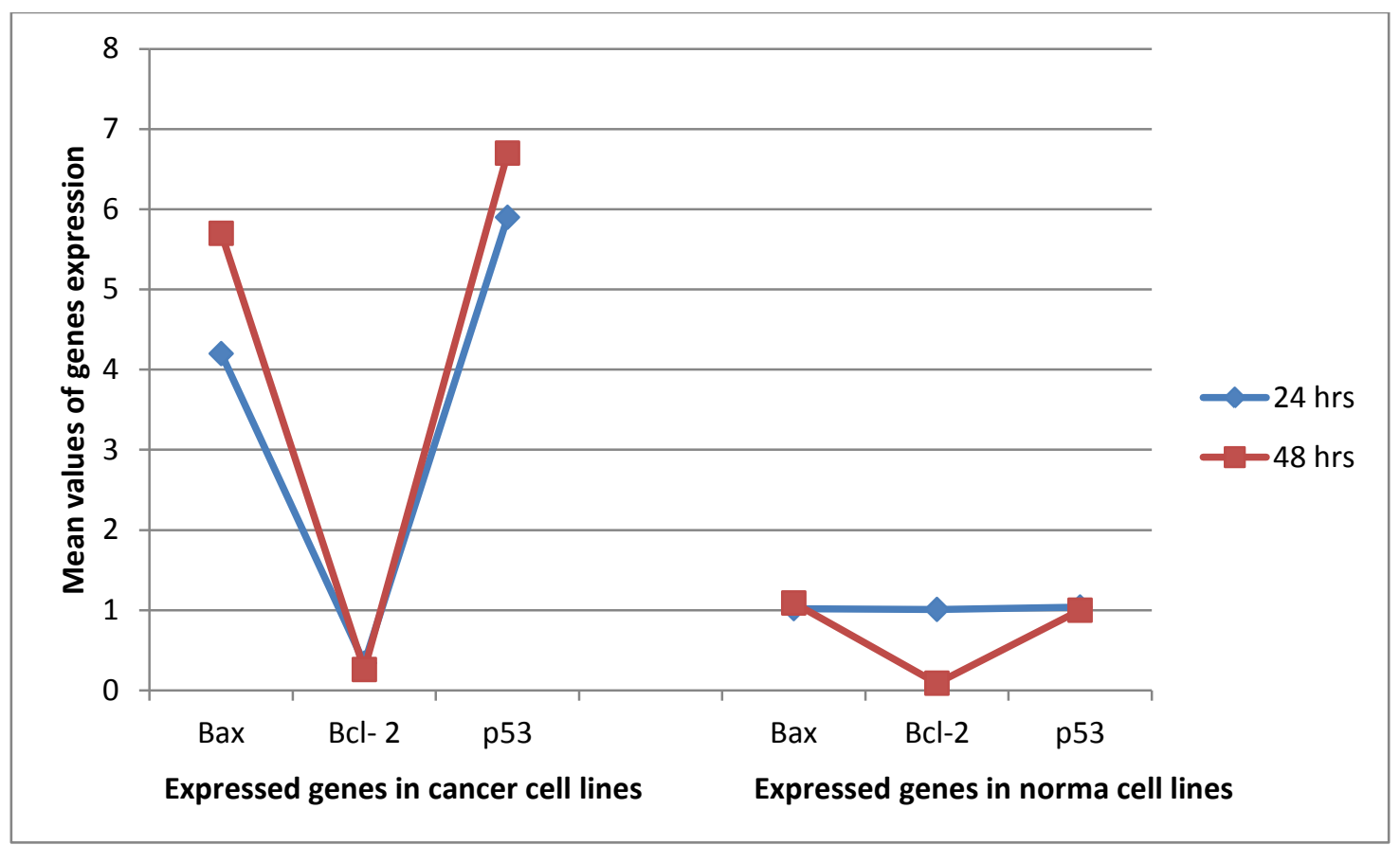

Graph 2:-Comparison of mean values of expressed genes in relation to time dependant.

\section{Discussion:-}

Cancer is a disease that characterized by uncontrolled proliferation of cells which may spread to different parts of the body. Angiogenesis is an important factor for proliferating and spreading of malignant cells. Rate of tumor growth depends on the balance between proliferation and apoptosis of the cells at the whole process of tumorgenesis (Carmeliet, 2003 and Cooper, 2000).

Recently, it is well known that natural products not only offer protection against oxidative reaction but also suppress proliferation of cancer cells in culture as well as in vivo (El-Awady et al., 2015). There are line of evidence indicating that medicinal plants constitute a common alternative for cancer prevention and treatment in many countries around the world (Sharma et al., 2017).

Approximately, $60 \%$ of the anticancer drugs currently used have been isolated from natural products from the plants. Multiple researchers worldwide have identified species of plants that have demonstrated anticancer properties with a lot of focus on those that have polyphenols, brassino steroids and taxols compounds (Greenwell and Rahman, 2015). Therefore, the present work was conducted to examine anticancer potential of punica granatum extract in nasopharyngeal carcinoma cell lines.

Punica granatum is an ancient and unique fruit borne on a small, long-living tree cultivated throughout the Mediterranean region, Himalayas in Southeast Asia and in the United States. It is used in several systems of medicine for a variety of diseases (Malik et al., 2005).

Antioxidant, anticarcinogenic and anti-inflammatory properties of pomegranate constituents have been published in numerous studies, focusing on treatment and prevention of cancer, cardiovascular disease, diabetes, bacterial infections, antibiotic resistance and ultraviolet radiation induced skin damage (Begum and Kumar, 2015).

Pomegranate extract exerts antiproliferative, anti-invasive, and antimetastatic effects, induces apoptosis through modulation of antiapototic proteins such as Bcl-2, increases p53, p21 and p27 (Faria andCalhau, 2011).

The results of our study confirmed that treatment with punica granatum extract inhibited cancer cell. This is consistent with earlier reports that reported growth inhibitory, proapoptotic and anti-invasive properties of 
pomegranate in different cancer cell lines (Adhami et al., 2009; Khan et al., 2009; Kasimsetty et al., 2010; Faria andCalhau, 2011 and Seidi et al., 2016).

Apoptosis is a genetically controlled process which promotes the beginning of carcinogenesis and cancer development when subjected to inhibition. Apoptosis is also associated with the expression of two synergistically acting genes that encode anti- and pro- apoptotic proteins. It is well known that Bcl-2 gene promotes cell survival while Bax gene enhances apoptosis, which is considered as dominant inhibitor of the action of Bcl-2 (Kobayashi, 2000; Reed, 2000; Cory and Adams 2002).

Mutation of p53 tumor suppressor gene is an important event in the development of malignant tumors. Cells with a mutated p53 gene tend to escape from apoptosis due to inactivation of p53 protein (Rivlin et al., 2011).

The current findings showed antiproliferative and cytotoxic effects of applied punica granatum extract on malignant cells obtained from nasopharyngeal carcinoma cell lines that increased in time dependant manner. Also, no antiproliferative effects on the normal cells have been revealed. The obtained results were in agreement with different studies (Abdel Motaal and Shakerb, 2011; Aqila et al., 2012; Banerjee et al., 2012 and Yazici et al., 2012), that were conducted to evaluate the apoptotic effect of different pomegranate extracts against different cancerous cell lines.

Antiproliferative potential and the apoptotic frequency in our study represented by an increase in the expression of Bax and p53 gene which were inversely proportional to the decreased expression of Bcl-2 gene. These findings were in the same line of previous studies (Cory et al., 2003 and Paul-Samojednya et al., 2005).

The two genes Bcl-2 and Bax genes are associated with the late signaling phase of apoptosis. The carcinogenic potential of Bcl-2 contributes to the accumulation of cells with damaged DNA that eradicated in normal conditions (Porebska et al., 2006 and Chen et al., 2015).

Cytotoxic effect of punica granatum was demonstated by many researches on many cancer cell lines including lung, breast, pancreatic and colon cancers while they revealed no effect on normal cell lines. These results came in accordance with our finding in which the added extract induced apoptosis of cancer cells without affecting normal cell lines (Wang et al., 2013; Zahin et al., 2014 and Nunez-Sanchez et al., 2015).

\section{Conclusion:-}

Punica granatum medicines have the potential to become a safe anti-carcinogenic agent. It has an inhibitory effect on C666-1 nasopharyngeal cancer cells proliferation through induction of apoptosis. These results offer justification for further studies to prove the anticancer activities on nasopharyngeal carcinoma cell lines.

\section{Conflict of Interest:-}

The authors declare that they have no conflict of interest.

\section{References:-}

1. Abdel Motaal, A. and Shakerb S. (2011): Anticancer and Antioxidant Activities of Standardized Whole Fruit, Pulp, and Peel Extracts of Egyptian Pomegranate. The Open Conference Proceedings Journal 2, 41-45.

2. Adhami VM, Khan N, Mukhtar H. (2009): Cancer chemoprevention by pomegranate: Laboratory and clinical evidence. Nutr Cancer 61, 811-815.

3. Ahmadi F., Mojarrab M., Ghazi-Khansari M., Hosseinzadeh L. (2015): A semipolar fraction of petroleum ether extract of Artemisia aucheri induces apoptosis and enhances the apoptotic response to doxorubicin in human neuroblastoma SKNMC cell line. Res Pharm Sci. 10:335-344.

4. Aqila F., Munagalaa R., Vadhanama M., Kausara H., Jeyabalana J., Schultzc D. et al. (2012): Anti-proliferative activity and protection against oxidative DNA damage by punicalagin isolated from pomegranate husk. Food Res Int. 1; 49(1): 345-353.

5. Baeshen, N., Elkady, O. Abuzinadah and Mutwakil, M. (2012): Potential anticancer activity of the medicinal herb, Rhazyastricta, against human breast cancer. African J. Biotechnol. 11 (37): 8960-8972.

6. Banerjee N., Talcott S, Safe S. and Mertens-Talcott, S. (2012): Cytotoxicity of pomegranate polyphenolics in breast cancer cells in vitro and vivo: potential role of miRNA-27a and miRNA-155 in cell survival and inflammation. Breast Cancer Res Treat. 136(1): 21-34. 
7. Begum Z. and Kumar N. (2015): Evaluation of Cytotoxic Effect of Punicagranatum L. varspinosa extracts on Malignant Cell Line MCF-7 in vitro. Molecular Enzymology and Drug Targets 1 (14): 1-6.

8. Carmeliet P. (2003): Angiogenesis in health and disease. Nat Med. 9:653-60.

9. Chen HS., Bai MH., Zhang T., Li GD., Liu M. (2015): Ellagic acid induces cell cycle arrest and apoptosis through TGF-beta/Smad3 signaling pathway in human breast cancer MCF-7 cells. Int. J. Oncol. 46, 1730-1738.

10. Cooper GM (2000): The cell: A Molecular Approach. $2^{\text {nd }}$ edition

11. Cory S, Huang CS and Adams MJ (2003): The Bcl-2 family: roles in cell survival and oncogenesis. Oncogene. 22, 8590-8607.

12. Cory S. and Adams J.M. (2002): The Bcl 2 family: regulators of the cellular life-or-death switch. Nat. Rev. Cancer 2 (9): 647-656

13. Dai Z., Nair V., Khan M., Ciolino H. (2010): Pomegranate extract inhibits the proliferation and viability of MMTV-Wnt-1 mouse mammary cancer stem cells in vitro. Oncol Rep 24:1087-1091.

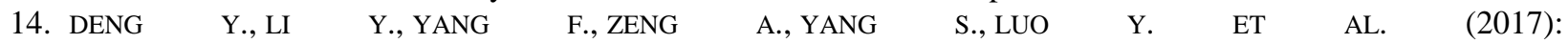
THE EXTRACT FROM PUNICAGRANATUM (POMEGRANATE) PEEL INDUCES APOPTOSIS AND IMPAIRS METASTASIS IN PROSTATE CANCER CELLS. BIOMED PHARMACOTHER. 93:976-984.

15. El-Awady M., Awad N. and El-Tarras A. (2015): Evaluation of the anticancer activities of pomegranate (Punicagranatum) and harmal (Rhazyastricta) plants grown in Saudi Arabia. Int.J.Curr.Microbiol.App.Sci 4 (5): $1158-1167$

16. Faria A. and Calhau C (2011): The bioactivity of pomegranate: Impact on health and disease. Crit. Rev. Food Sci. Nutr., 51, 626-634.

17. Felipe K., Kviecinski M., da Silva F., Bücker N., Farias M., Porfirio Will Castro L., et al. (2014): Inhibition of tumor proliferation associated with cell cycle arrest caused by extract and fraction from Caseariasylvestris (Salicaceae). J Ethnopharmacol 155 (3):1492-1499.

18. Global Burden of Disease Cancer Collaboration (2017): Fitzmaurice C, Allen C, et al. Global, Regional, and National Cancer Incidence, Mortality, Years of Life Lost, Years Lived With Disability, and Disability-Adjusted Life-years for 32 Cancer Groups, 1990 to 2015: A Systematic Analysis for the Global Burden of Disease Study. JAMA Oncol 3 (4):524-548.

19. Greenwell M. and Rahman P. (2015): Medicinal Plants: Their Use in Anticancer Treatment. Int J Pharm Sci Res. 6 (10): 4103-4112.

20. Jurenka J. (2008): Therapeutic applications of pomegranate (Punicagranatum L.): A review. Altern. Med. Rev. $13,128-144$.

21. Kasimsetty SG, Bialonska D, Reddy MK, Ma G, Khan SI, Ferreira D. (2010): Colon cancer chemopreventive activities of pomegranate ellagitannins and urolithins. J Agric Food Chem 58, 2180-2187.

22. Khan GN, Gorin MA, Rosenthal D, Pan Q, Bao LW, Wu ZF. et al. (2009): Pomegranate fruit extract impairs invasion and motility in human breast cancer. Integr Cancer Ther 8, 242-253.

23. Kobayashi T., Sawa H., Morikawa J., Zhang W., Shiku H. (2000): Bax induction activates apoptotic cascade via mitochondria cytochrome $\mathrm{c}$ release and Bax of the expression enhances apoptosis induced by chemotherapeutic agents in DLD-1 colon cancer cells. Jpn. J. Cancer Res. 91 (12): 1264-1268

24. Kuppusamy P., Yusoff M., Maniam G., Govindan N. (2013): A case study regulation and functional mechanisms of cancer cells and control its activity using plants and their derivatives. J Pharm Res. 6:884-892.

25. Malik A., Afaq F., Sarfaraz S., Adhami VM, Syed DN, Mukhtar H. (2005): Pomegranate fruit juice for chemoprevention and chemotherapy of prostate cancer. ProcNatlAcadSci U S A 102 (4): 14813-14818.

26. Nunez-Sanchez MA., Davalos A., Gonzalez-Sarrias A., Casas-Agustench P., Visioli F., Monedero-Saiz T. et al. (2015): MicroRNAs expression in normal and malignant colon tissues as biomarkers of colorectal cancer and in response to pomegranate extracts consumption: Critical issues to discern between modulatory effects and potential artifacts. Mol. Nutr. Food Res. 59, 1973-1986.

27. Paul-Samojednya M., Kokocińskab D., Samojednya A., Mazureka U., Partykab R., Lorenzb Z. et al. (2005): Expression of cell survival/death genes: $\mathrm{Bcl}-2$ and $\mathrm{Bax}$ at the rate of colon cancer prognosis. BiochemBiophysActa 1741(1-2): 25-29.

28. Porebska I, Wyrodek E, Kosacka M, Adamiak J, Jankowska R, Harłozińska-Szmyrka A. (2006): Apoptotic markers p53, Bcl-2 and Bax in primary lung cancer. In Vivo 20 (5): 599-604.

29. Portt L., Norman G., Clapp C., Greenwood M., Greenwood M.T. (2011): Anti-apoptosis and cell survival: a review. BiochimBiophysActa. 18 (13):238-259.

30. Reed JC. (2000): Mechanisms of apoptosis. A.m. J. Pathol. 157, 1415-1426

31. Rivlin N, Brosh R, Oren M and Varda Rotter V. (2011): Mutations in the p53 Tumor Suppressor Gene. Important Milestones at the Various Steps of Tumorigenesis. Genes Cancer 2, 466-474. 
32. Saini R., Chouhan R., Bagri L. and Bajpai K. (2012): Strategies of Targeting Tumors and Cancers. J. Can. Res. Update 1 (1): 129-152.

33. Seidi K., Jahanban-Esfahlan R., Abasi M., Abbasi M. (2016): Anti Tumoral Properties of Punicagranatum (Pomegranate) Seed Extract in Different Human Cancer Cells. Asian Pac J Cancer Prev. 17(3):1119-22

34. Sharma P., McClees S., Afaq F. (2017): Pomegranate for Prevention and Treatment of Cancer: An Update. Molecules 22 (1).

35. Shirode A., Kovvuru P., Chittur S., Henning S., Heber D., Reliene R. (2014): Antiproliferative Effects of Pomegranate Extract in MCF-7 Breast Cancer Cells are Associated with Reduced DNA Repair Gene Expression and Induction of Double Strand Breaks Molecular Carcinog. 53 (6):458-470.

36. Shojaee S., Parhiz H., Eshaghi A., Emami S., Asili J., Mosaffa F. (2014): In vitro protective effects of Scutellarialitwinowii root extract against H2O2 -induced DNA damage and cytotoxicity. J Complement Integr Med. 11:121-127.

37. Thangam R, Sathuvan M, Poongodi A, Suresh V, Pazhanichamy K, Sivasubramanian S, et al. (2014): Activation of intrinsic apoptotic signaling pathway in cancer cells by Cymbopogoncitratus polysaccharide fractions. CarbohydrPolym. 107:138-150.

38. Wang Y., Zhang S., Iqbal S., Chen Z., Wang X., Wang YA. Et al. (2013): Pomegranate extract inhibits the bone metastatic growth of human prostate cancer cells and enhances the in vivo efficacy of docetaxel chemotherapy. Prostate 74, 497-508.

39. Yazici, Z., Meric A., Midi A., ArÂnc Y., Kahya V. and HafÂz, G. (2012): Reduction of cisplatin ototoxicity in rats by oral administration of pomegranate extract. Eur Arch Otorhinolaryngol. 269: 45-52.

40. Zahin M., Ahmad I., Gupta RC.,Aqil F. (2014): Punicalagin and ellagic acid demonstrate antimutagenic activity and inhibition of benzo[a]pyrene induced DNA adducts. Biomed. Res. Int. 2014, 467-465. 